\title{
Organic acids as feed additives for young pigs: Nutritional and gastrointestinal effects
}

\author{
F.X. Roth and M. Kirchgessner \\ Institute of Nutrition Physiology, Technical University of Munich \\ D-85350 Freising-Weihenstephan, Germany
}

\begin{abstract}
Experimental data show that a significant improvement of growth rate and feed conversion rate of weanling pigs can be achieved by the inclusion of organic acids in the diet. These ergotropic effects have been mainly observed with formic, lactic, sorbic, fumaric, citric and malic acid as well as with different salts of formic acid. The lowering of dietary $\mathrm{pH}$ alone, with inorganic acids (o-phosphoric acid, $\mathrm{HCl}$ ), however failed to show any nutritive efficacy. Studies on the mode of action of organic acids indicate that they cause a higher protein and energy digestibility and retention, an alteration of bacterial populations and metabolites in the gastrointestinal tract and possibly an effect on metabolism. It seems likely that the antimicrobial properties of organic acids and of their salts are of great importance for their beneficial effects in weanling pigs.
\end{abstract}

KEY WORDS: organic acid, pig, growth promotion, digestibility, microbiology

\section{INTRODUCTION}

The positive effects on the performance of weanling pigs, of adding organic acids or their salts to the feed, has been proven many times with various chemical compounds (for review see Kirchgessner and Roth, 1982a, 1988, 1991; Gabert and Sauer, 1994). The growth promoting effects of organic acids are usually most predominant within a few weeks of weaning. Pigs weaned at 3 to 4 weeks of age, often exhibit a low weight gain, low feed intake and diarrhoca. This is usually called "the post-weaning check, or lag period," which may be the result of the not yet fully developed digestive functions. According to Kidder and Manners (1978) this particularly concerns insufficient secretions of gastric $\mathrm{HCl}$, and pancreatic amylase, lipase and trypsin. Low $\mathrm{HCl}$ secretion can lead to proliferation of intestinal bacteria. This can have detrimental effects for the piglet and explains the particu- 
lar susceptibility of young piglets to digestive disorders. Supplementing diets with feed antibiotics to prevent diarrhoea has been a matter of negative public debate, because of the potential sclection of resistant strains of pathogenic bacteria. As a result, an interest has developed in "biological" fecd additives, such as organic acids.

Some objectives of dietary acidification are: a lower dietary $\mathrm{pH}$ value and buffering capacity, in order to increase gastric proteolysis and nutrient digestibility, and a decrease in intestinal bacterial growth and bacterial metabolites, from which the anabolic potential for growth may be enhanced. The present review summarizes the effects of organic acid supplementation on growth performance, and is exemplified by some effects of formic acid on the gastrointestinal milieu - including bacterial counts in weancd piglets.

\section{GROWTH PROMOTING EFFECTS}

Table 1 summarizes results from studies on the growth promoting effects of monocarboxylic acids added at various levels to the feed of piglets, weaned at an age of 3 to 4 weeks. All experiments cited lasted about 6 wecks and involved individual feeding, ad libitum, and were at a high hygienic standard. The feed mixtures used were complex diets. For the first 3 experimental weeks a prestarter type of $\operatorname{diet}(23 \% \mathrm{CP} ; 13.4 \mathrm{MJ} \mathrm{ME} / \mathrm{kg}$ ) was used, while for the following 3 weeks a starter diet $(18.5 \% \mathrm{CP} ; 13 \mathrm{MJ} \mathrm{ME} / \mathrm{kg})$ was used. The diets were formulated to meet or exceed the nutrient requirement standards given by the Society of Nutrition Physiology (GfE, 1987). The acids were always added to the feed on a nitrogen and energy equivalent basis. The results showed that formic, lactic and sorbic acid improved daily weight gain (DWG) and feed conversion rate (FCR) by up to 22.1 and $7.5,8.1$ and $1.8,26.7$ and $6.5 \%$, respectively. Supplementing weanling pig diets with acetic or propionic acid improved performance to a much lower extent or not at all. Potential reasons for the variable results between these studies are: the kind of acid, the dose level, a depressive effect on feed intake and the health status of the animals. Within the dose ranges used, $1.2 \%$ formic, $1.6 \%$ lactic and $2.4 \%$ sorbic acid were the most effective and may therefore be regarded as the optimal doses. These additives may also decrease the incidence of diarrhoea, as obscrved in a number of studies (Roth and Kirchgessner, 1997).

Besides these monocarboxylic acids, which (apart from sorbic acid) are products of bacterial metabolism in the intestinal tract, acids which are natural intermediates of the citric acid cycle of the cells are also used for supplementing piglet feeds. Notable among these di- and tricarboxylic acids are fumaric and citric acid, which have both been used for a long time in piglet rearing. Table 2 shows some results for these acids in piglet feeding trials. Fumaric, citric and malic acid improved DWG and FCR by up to 11.6 and $7.0 \%, 18.7$ and $8.7 \%, 4.0$ and $4.8 \%$, 
TABLE 1

The effect of monocarboxylic acid supplementation on weanling pig performance

\begin{tabular}{lccccccl}
\hline Acid & $\%^{\prime}$ & $\mathrm{BW}^{2}$ & $\mathrm{DWG}^{3}$ & $\% \Delta^{4}$ & $\mathrm{FCR}^{5}$ & $\Delta^{6} \%^{6}$ & Reference \\
\hline Formic & 0.6 & 6.1 & 463 & $+21.8^{*}$ & $1.46^{*}$ & -5.6 & Eckel et al., 1992 \\
& 1.2 & 6.1 & 468 & $+22.1^{*}$ & $1.43^{*}$ & -7.5 & \\
& 1.8 & 6.1 & 401 & +4.6 & 1.53 & -1.0 & \\
& 2.4 & 6.1 & 325 & $-15.1^{*}$ & 1.60 & +3.9 & \\
Acetic & 0.9 & 5.6 & 415 & -2.1 & 1.77 & +1.1 & Roth and Kirchgessner, 1988 \\
& 1.8 & 5.6 & 429 & +1.2 & 1.72 & -1.7 & \\
& 2.7 & 5.6 & 441 & +4.0 & 1.70 & -2.9 & \\
Propionic & 1.0 & 5.6 & 388 & -3.2 & 1.78 & +1.1 & Kirchgessner and Roth, $1982 \mathrm{~b}$ \\
& 2.0 & 5.6 & 385 & -4.0 & 1.80 & +2.2 & \\
& 3.0 & 5.6 & 395 & -1.5 & 1.74 & -1.1 & \\
Lactic & 0.8 & 6.8 & 489 & +4.7 & 1.65 & +1.2 & Roth et al., 1993 \\
& 1.6 & 6.8 & 505 & +8.1 & 1.60 & -1.8 & \\
& 2.4 & 6.8 & 501 & +7.3 & 1.60 & -1.8 & \\
& & & & & & & Kirchgessner et al., 1995 \\
Sorbic & 1.2 & 7.2 & 490 & $+13.7^{*}$ & $1.63^{*}$ & -4.1 & \\
& 1.8 & 7.2 & 523 & $+21.3^{*}$ & $1.60^{*}$ & -5.9 & \\
& 2.4 & 7.2 & 546 & $+26.7^{*}$ & $1.59^{*}$ & -6.5 & \\
\hline
\end{tabular}

1 inclusion level of acid in the diet

2 initial body weight, $\mathrm{kg}$

${ }^{3}$ average daily weight gain, $\mathrm{g}$

${ }^{4}$ percentage increase/decrease in DWG relative to control

5 feed conversion rate as $g$ feed per $g$ weight gain

"percentage improvement $(-) /$ deterioration ( + ) in FCR relative to control

* significantly different $(\mathrm{P}<0.05)$ from control

respectively. Within the dose levels used, $2 \%$ fumaric, $4.5 \%$ citric and $2.4 \%$ malic acid showed the strongest performance responses and these may be regarded as the optimal doses. In contrast to these results, supplementing the piglet diet with succinic, adipic or tartaric acid produced no positive response on DWG or FCR. In the case of tartaric acid, there was even a dose-dependent growth depression. The main reason for this poor or negative response by these last mentioned supplements was their low dietary acceptance and the corresponding reduction in feed intake.

In recent years, organic salts have been coming more and more under consideration as dietary supplements because they are easier to handle, doses can be more accurately measured, and they are less corrosive than the free acids. Thus, formates, as well as free formic acid, have been demonstrated to improve performance of weanling pigs (Table 3 ). When diets for weanling pigs were supplemented with Na-formate, Ca-formate or K-diformate DWG and FCR could be improved by up to 4.9 and $5.4 \%, 9.3$ and $4.6 \%, 22.9$ and $7.5 \%$, respectively. The best results in DWG were obtained at a dose level of $1.8 \% \mathrm{Na}$-formate, $1.3 \% \mathrm{Ca}$-formate and 
TABLE 2

The effect of di-/tricarboxylic acid supplementation on weanling pig performance

\begin{tabular}{|c|c|c|c|c|c|c|c|}
\hline Acid & $\%$ & $\mathrm{BW}^{2}$ & $\mathrm{DWG}^{3}$ & $\% \Delta^{4}$ & $\mathrm{FCR}^{5}$ & $\Delta \%$ & Reference \\
\hline Fumaric & $\begin{array}{l}0.5 \\
1.0 \\
2.0 \\
4.0\end{array}$ & $\begin{array}{l}7.8 \\
7.8 \\
7.8 \\
7.8\end{array}$ & $\begin{array}{c}513 \\
559 \\
625^{*} \\
581\end{array}$ & $\begin{array}{r}-8.4 \\
+0.1 \\
+11.6 \\
+3.8\end{array}$ & $\begin{array}{l}1.53 \\
1.50 \\
1.45^{*} \\
1.48^{*}\end{array}$ & $\begin{array}{l}-2.0 \\
-3.9 \\
-7.0 \\
-5.1\end{array}$ & Kirchgessner and Roth, 1976 \\
\hline Citric & $\begin{array}{l}0.5 \\
1.5 \\
4.5\end{array}$ & $\begin{array}{l}13.9 \\
13.9 \\
13.9\end{array}$ & $\begin{array}{l}443 \\
403 \\
502\end{array}$ & $\begin{array}{c}+4.7 \\
-4.7 \\
+18.7 *\end{array}$ & $\begin{array}{l}1.98 \\
2.19 \\
1.90^{*}\end{array}$ & $\begin{array}{r}-4.8 \\
+5.2 \\
-8.7\end{array}$ & Kirchgessner and Roth-Maier, 1975 \\
\hline Succinic & $\begin{array}{l}0.8 \\
1.6 \\
2.4\end{array}$ & $\begin{array}{l}7.3 \\
7.3 \\
7.3\end{array}$ & $\begin{array}{l}465 \\
441 \\
450\end{array}$ & $\begin{array}{l}+2.2 \\
-3.1 \\
-1.1\end{array}$ & $\begin{array}{l}1.52 \\
1.57 \\
1.52\end{array}$ & $\begin{array}{r}-1.3 \\
+1.9 \\
-1.3\end{array}$ & Unpublished \\
\hline Malic & $\begin{array}{l}1.2 \\
1.8 \\
2.4\end{array}$ & $\begin{array}{l}6.5 \\
6.5 \\
6.5\end{array}$ & $\begin{array}{l}465 \\
452 \\
456\end{array}$ & $\begin{array}{l}+4.0 \\
+1.1 \\
+2.0\end{array}$ & $\begin{array}{l}1.59^{*} \\
1.59^{*} \\
1.57^{*}\end{array}$ & $\begin{array}{l}-3.6 \\
-3.6 \\
-4.8\end{array}$ & Kirchgessner et al., 1993 \\
\hline Adipic & $\begin{array}{l}0.6 \\
1.2 \\
1.8\end{array}$ & $\begin{array}{l}7.2 \\
7.2 \\
7.2\end{array}$ & $\begin{array}{l}472 \\
470 \\
476\end{array}$ & $\begin{array}{l}-1.3 \\
-1.9 \\
-0.6\end{array}$ & $\begin{array}{l}1.56 \\
1.56 \\
1.56\end{array}$ & $\begin{array}{l}-1.3 \\
-1.3 \\
-1.3\end{array}$ & Unpublished \\
\hline Tartaric & $\begin{array}{l}1.2 \\
1.8 \\
2.4\end{array}$ & $\begin{array}{l}6.6 \\
6.6 \\
6.6\end{array}$ & $\begin{array}{l}449 \\
453 \\
433\end{array}$ & $\begin{array}{r}-7.2 \\
-6.4 \\
-10.5\end{array}$ & $\begin{array}{l}1.64 \\
1.65 \\
1.64\end{array}$ & $\begin{array}{l}-3.0 \\
-2.4 \\
-3.0\end{array}$ & Kirchgessner et al., 1993 \\
\hline
\end{tabular}

1 inclusion level of acid in the diet

${ }^{2}$ initial body weight, $\mathrm{kg}$

"average daily weight gain, $g$

${ }^{4}$ percentage increase/decrease in DWG relative to control

${ }^{5}$ feed conversion rate as $\mathrm{g}$ feed per g weight gain

${ }^{6}$ percentage improvement $(-)$ /deterioration $(+)$ in $\mathrm{FCR}$ relative to control

* significantly different $(\mathrm{P}<0.05)$ from control

$2 \% \mathrm{~K}$-diformate. However, neither $\mathrm{Na}$ - nor $\mathrm{Ca}$-formate were as efficient growth promoters as free formic acid (according to the acid anion proportion in these formates). These neutral reacting salts are more efficient if they are used in combination with the free acid (Kirchgessner and Roth, 1990). On the other hand, potassium diformate produced by a new technology, binds a certain amount of free formic acid without evaporation, and that makes this compound particularly efficient and suitable for practical feeding purposes (Roth et al., 1996).

One of the objectives of dictary acidification for piglets is to attain a lower dietary $\mathrm{pH}$ and buffering capacity in order to support gastric proteolysis. This raises the question of whether simply lowering dietary $\mathrm{pH}$, by the inclusion of an inorganic acid, is also beneficial for the piglet. As shown in Table 4, the inclusion of up to $3.55 \%$ o-phosphoric acid did not influence weanling pig performance. 
TABLE 3

The effect of formates supplementation on weanling pig performance

\begin{tabular}{lccccccl}
\hline Acid & $\%^{1}$ & $\mathrm{BW}^{2}$ & $\mathrm{DWG}^{3}$ & $\% \Delta^{4}$ & $\mathrm{FCR}^{5}$ & $\Delta^{\dagger}{ }^{\dagger}$ & Reference \\
\hline Na-formate & 0.9 & 5.6 & 458 & +2.0 & $1.59^{*}$ & -4.2 & Kirchgessner and Roth, 1987a \\
& 1.8 & 5.6 & 471 & +4.9 & $1.61^{*}$ & -3.0 & \\
Ca-formate & 1.3 & 6.7 & 452 & +7.1 & $1.78^{*}$ & -3.8 & Kirchgessner and Roth, 1987b \\
& 2.6 & 6.7 & 415 & -1.7 & 1.79 & -3.3 & \\
Ca-formate & 1.3 & 7.0 & 459 & +9.3 & $1.65^{*}$ & -4.6 & Kirchgessner and Roth, 1990 \\
K-di- & 0.4 & 7.5 & 518 & +7.2 & 1.57 & -1.3 & Paulicks et al., 1996 \\
formate & & & & & \\
& 0.8 & 7.5 & 509 & +5.4 & 1.55 & -2.5 & \\
& 1.2 & 7.5 & 535 & +10.8 & 1.58 & -0.6 & \\
& 1.6 & 7.5 & $559^{*}$ & +15.7 & $1.53^{*}$ & -3.8 & \\
& 2.0 & 7.5 & $589 *$ & +22.9 & $1.49^{*}$ & -6.3 & \\
& 2.4 & 7.5 & 543 & +12.4 & $1.47^{*}$ & -7.5 & \\
\hline
\end{tabular}

1 inclusion level of acid in the diet

2 initial body weight, $\mathrm{kg}$

${ }^{3}$ average daily weight gain, $\mathrm{g}$

${ }^{4}$ percentage increase/decrease in DWG relative to control

${ }^{5}$ feed conversion rate as $\mathrm{g}$ feed per $\mathrm{g}$ weight gain

${ }^{6}$ percentage improvement $(-)$ /deterioration $(+)$ in FCR relative to control

${ }^{7}$ Formi"m LHS produced by Norsk Hydro a.s., Oslo

* significantly different $(\mathrm{P}<0.05)$ from control

TABLE 4

The effect of inorganic acid supplementation on weanling pig performance

\begin{tabular}{llcccccl}
\hline Acid & $\%^{1}$ & $\mathrm{BW}^{2}$ & $\mathrm{DWG}^{3}$ & $\% \Delta^{4}$ & $\mathrm{FCR}^{5}$ & $\Delta \%{ }^{6}$ & Reference \\
\hline o-Phosphoric & 0.85 & 6.4 & 451 & 0 & 1.64 & +1.2 & Roth and Kirchgessner, 1989 \\
& 1.70 & 6.4 & 444 & -1.6 & 1.62 & 0 & \\
& 2.55 & 6.4 & 464 & +2.9 & 1.61 & -0.6 & \\
o-Phosphoric & 3.55 & 7.0 & 349 & +2.0 & 1.75 & -9.0 & Giesting and Easter, 1986 \\
Hydrochloric & 3.0 & 7.0 & $211^{*}$ & -38.0 & 2.04 & +6.0 & Giesting and Easter, 1986 \\
Hydrochloric & 1.4 & 5.8 & $329^{*}$ & -16.5 & 1.48 & +1.0 & Eidelsburger et al., 1992 \\
Calcium- & 0.33 & 7.3 & 445 & +3.6 & 1.55 & +1.3 & Unpublished \\
chloride & 0.66 & 7.3 & 389 & -8.4 & 1.54 & +0.7 & \\
$\left(\right.$ CaCl $\left._{2} \cdot 2 \mathrm{H}_{2} \mathrm{O}\right)$ & 1.00 & 7.3 & 397 & -7.6 & 1.56 & +2.0 & \\
\hline
\end{tabular}

1 inclusion level of acid in the diet

2 initial body weight, $\mathrm{kg}$

${ }^{3}$ average daily weight gain, $\mathrm{g}$

${ }^{4}$ percentage increase/decrease in DWG relative to control

${ }^{5}$ feed conversion rate as $\mathrm{g}$ feed per g weight gain

"percentage improvement $(-)$ /deterioration $(+)$ in $\mathrm{FCR}$ relative to control

* significantly different $(\mathrm{P}<0.05)$ from control 
Supplemention by $\mathrm{HCl}$ or calcium chloride exerted a strong growth depression, duc to a reduction in feed intake and a severe disturbance of the pig's acid-basebalance. From these data it seems that the nutritive efficacy is not a function of the lowering of dietary $\mathrm{pH}$ (i.e. a proton effect), but that it is more dependent on the kind of the acid anion (Kirchgessner and Roth, 1987a,b, 1990).

\section{MODE OF ACTION}

The growth promoting effects of organic acids may be due to increased nutrient and energy digestibility and retention, alteration of bacterial populations and metabolites in the gastrointestinal tract and/or an effect on metabolism. Because of its high nutritional efficacy formic acid has been used to investigate the mode of action of organic acids. Formic acid supplementation positively influenced nutrient digestibility (Eckel et al., 1992). Improvements were higher for protein (up to 4\%) than for energy (up to $2 \%$ ) and were more pronounced in the period shortly after weaning than at a later age. For optimal digestion of proteins in the digestive tract, it is necessary that the pepsinogen produced in the stomach is converted to pepsin. A pH below 5.0 is required for this conversion, while pepsin activity is optimal only at $\mathrm{pH} 2.0$ to 3.5 (Taylor, 1959). Dietary acidification reduces the buffering capacity of the diet and this may support a more efficient proteolysis of digesta in the stomach and therefore result in a higher protein digestibility of the diet.

Corresponding to the previously mentioned growth data (see Table 1) the protein and fat accretions of the piglets were increased together with dietary formic acid supply (Kirchgessner et al., 1992a). The highest responses in protein and fat depositions were found at dosage levels of 0.6 and $1.2 \%$ formic acid; increasing formic acid dosage above this level reduced both accretions (fat more than protein). Energy and especially protein utilization were both improved by formic acid

TABLE 5

Effect of dietary formic acid supplementation on microorganism counts ${ }^{1}$ in the digesta of different segments of the gastrointestinal tract of piglets (Kirchgessner et al., 1992b)

\begin{tabular}{|c|c|c|c|c|c|c|c|c|}
\hline \multirow{2}{*}{$\begin{array}{l}\text { Species } \\
\text { Formic acid suppl., \% }\end{array}$} & \multicolumn{2}{|c|}{$\begin{array}{l}\text { Lactobacillus } \\
\text { /Bifidobacterium }\end{array}$} & \multicolumn{2}{|c|}{ E. coli } & \multicolumn{2}{|c|}{ Bacteroidaceae } & \multicolumn{2}{|c|}{ Enterococci } \\
\hline & 0 & 1.2 & 0 & 1.2 & 0 & 1.2 & 0 & 1.2 \\
\hline Duodenum & 6.4 & 5.5 & $5.5^{\mathrm{a}}$ & $3.3^{b}$ & $4.1^{4}$ & $2.1^{\mathrm{b}}$ & $3.2^{\mathrm{a}}$ & $2.3^{b}$ \\
\hline Jejunum & $6.7^{\mathrm{a}}$ & $5.8^{\mathrm{b}}$ & $6.8 \mathrm{a}$ & $5.3^{b}$ & $4.5^{\mathrm{a}}$ & $3.0^{\mathrm{b}}$ & 4.5 & 3.7 \\
\hline lleum & 7.2 & 6.6 & 7.9 & 6.8 & 5.7 & 4.8 & 5.6 & 5.2 \\
\hline Caecum & 8.1 & 7.5 & 6.8 & 6.9 & 6.6 & 6.2 & 4.4 & 4.9 \\
\hline Colon & 8.6 & 8.0 & 6.3 & 6.0 & 6.6 & 5.7 & 4.3 & 4.5 \\
\hline
\end{tabular}

1 colony forming units (CFU) in ${ }^{10} \mathrm{log} / \mathrm{g}$ fresh matter

u. b significantly different $(\mathrm{P}<0.05)$ from control 
treatments. It appears that the formic acid treatment made the protein metabolism more efficient.

Organic acids exert various, specific antimicrobial properties. Formic acid for example acts against yeasts and certain bacterial species, such as Bacillus spp., E. coli and Salmonella; but Lactobacilli and moulds are rather resistent to formic acid (Rehm, 1961). The effect of dietary formic acid supplementation on microorganism counts in the digesta of different segments of the gastrointestinal tract in piglets is given in Table 5. Supplementation with formic acid did not greatly affect the bacterial populations in ileum, caecum and colon digesta, however the number of E. coli, Bacteroidaceae and Enterococci in the duodenum and jejunum were significantly decreased. The counts of Lactobacilli were generally lowered to a smaller extent. This antibacterial effect might be explained by the protons ( $\mathrm{H}^{\prime}$ ions) and anions ( $\mathrm{HCOO}^{-}$ions) into which formic acid is divided after passing the bacterial cell wall and which have a disruptive effect on bacterial protein synthesis (Lück, 1986). In practical terms this means that the bacterial cells are placed under considerable stress and are unable to replicate. There is some evidence from the literature that fumaric and propionic acid, as well as formic acid, decrease intestinal microbial growth; this may be beneficial for the weanling pig (Bolduan et al., 1988; Sutton et al., 1991; Gedek et al., 1992).

Regarding the intestinal milieu, formic acid did not significantly influence the $\mathrm{pH}$ value or the concentrations of dry matter or volatile fatty acids in the various segments of the intestinal tract (Roth et al., 1992). However, there was a significant decrease of $\mathrm{NH}_{3}$ in the stomach and of lactic acid in the small intestine, while the concentrations of formic acid in these segments were elevated depending on the dietary inclusion rate, but no formic acid was detectable in the caecum or colon. In similar manner, dictary supplementation with citric or propionic acid, as with fumaric acid, also had no influence on $\mathrm{pH}$ value, $\mathrm{Cl}$ or volatile fatty acid content in the stomach or small intestine (Sutton et al., 1991; Risley et al., 1992).

The effects of organic acid supplementation on the chemical composition of the gastrointestinal chyme are not always consistent. One reason for this is that digesta samples are often taken at the conclusion of a growth trial. By this time the digestive system of the weanling pig may be fully developed, as has been pointed out by Gabert and Sauer (1994). There is no doubt that more research is needed to improve our understanding of the mode of action of organic acids.

\section{IMPLICATIONS}

The improvements in performance attained by dietary acidification are mainly considered to be a response to the reduced dietary $\mathrm{pH}$ and buffering capacity. However, it has not yet been possible to attain a growth promoting effect in piglets only 
by lowering the $\mathrm{pH}$ value and the buffering capacity of the feed with inorganic acids like phosphoric or hydrochloric acid. On the other hand, neutral reacting organic salts such as sodium or calcium formate, also improve performance, without producing a marked change in dietary acidity. Therefore, the reported benefits of including organic acids should perhaps be rather attributed to the antimicrobial properties of the acid anion which, as has been shown for formic acid, efficiently controls the bacterial population in the upper intestinal tract.

\section{REFERENCES}

Bolduan V.G., Jung H., Schneider R., Block J., Klenke B., 1988. Die Wirkung von Propion- und Amcisensäure in der Ferkelaufzucht. J. Anim. Physiol. Anim. Nutr. 59, 73-78

Eckel B., Kirchgessner M., Roth F.X., 1992. Zum Einfluß von Ameisensäure auf tägliche Zunahmen, Futteraufnahme, Futterverwertung und Ver-daulichkeit. J. Anim. Physiol. Anim. Nutr. 67, 93-100

Eidelsburger U., Kirchgessner M., Roth F.X., 1992. Zum Einfluß von Fumar-säure, Natriumformiat, Tylosin und Toyocerin auf tägliche Zunahmen, Futteraufnahme, Futterverwertung und Verdaulichkeit. J. Anim. Physiol. Anim. Nutr. 68, 82-92

Gabert V.M., Sauer W.C., 1994. The effects of supplementing diets for weanling pigs with organic acids. A review. J. Anim. Feed. Sci. 3, 73-87

Gedek B., Roth F.X., Kirchgessner M., Wiehler S., Bott A., Eidelsburger U., 1992. Zum Einfluß von Fumarsäure, Salzsäure, Natriumformiat, Tylosin und Toyocerin auf die Keimzahlen der Mikroflora und deren Zusammensetzung in verschiedenen Segmenten des Gastrointestinaltraktes. J. Anim. Physiol. Anim. Nutr. 68, 209-217

$\mathrm{GfE}$ (Gesellschaft für Emährungsphysiologie), 1987. Energie- und Nährstoffbedarf landwirtschaftlicher Nutztiere. Nr. 4 Schweine. DLG-Verlag, Frankfurt/M., Germany

Giesting D.W., Easter R.A., 1986. Acidification. Status in swine diets. Feed Mange. 37, 8-10

Kidder D.E., Manners M.J.. 1978. Digestion in Pig. Scientechnica. Bristol, UK

Kirchgessner M., Eckel B., Roth F.X., Eidelsburger U., 1992a. Einfluß von Ameisensäure auf Körperzusammensetzung und Nährstoffretention. J. Anim. Physiol. Anim. Nutr. 67, 101-110

Kirchgessner M., Gedek B., Wiehler S., Bott A., Eidelsburger U., Roth F.X., 1992b. Zum Einfluß von Ameisensäure, Calciumformiat und Natrium-hydrogencarbonat auf die Keimzahlen der Mikroflora und deren Zusammensetzung in verschiedenen Segmenten des Gastrointestinaltraktes. J. Anim. Physiol. Anim. Nutr. 67, 73-81

Kirchgessner M., Roth F.X., 1976. Zum Einsat7. von Fumarsäure in der Ferkelaufzucht. Züchtungskunde 48, 402-406

Kirchgessner M., Roth F.X., 1982a. Fumaric acid as a feed additive in pig nutrition. Pig News Inf. 3, 259-264

Kirchgessner M., Roth F.X., 1982b. Propionsäure als Futteradditiv in der Fcrkelaufzucht und Schweinemast. Wirtschaftseig. Fulter 28, 225-234

Kirchgessner M., Roth F.X., 1987a. Zum Einsatz von Formiaten in der Ferkelfütterung. 2. Mitteilung. Natriumformiat. Landwirtsch. Forsch. 40, 287-294

Kirchgessner M., Roth F.X., 1987b. Use of formate in the feeding of piglets. 1. Communication. Calcium formate. Landwirtsch. Forsch, 40, 141-152 
Kirchgessner M., Roth F.X., 1988. Ergotrope Effekte durch organische Säuren in der Ferkelaufzucht und Schweinemast. Übers. Tierernähr. 10,93-108

Kirchgessner M., Roth F.X., 1990. Nutritive effect of calcium formate in combination with frec acids in the feeding of piglets. Agribiol. Res. 43, 53-64

Kirchgessner M., Roth F.X., 1991. Ergotrope Effekte durch nutritiven Einsatz von organischen Säuren. Zbl. Hyg. 191, 265-276

Kirchgessner M., Roth F.X., Eidelsburger U., 1993. Zur nutritiven Wirksamkeit von Weinsäure und Äpfelsäure in der Ferkelaufzucht. J. Anim. Physiol. Anim. Nutr. 70, 216-224

Kirchgessner M., Roth F.X., Paulicks B.R., 1995. Zur nutritiven Wirksamkeit von Sorbinsäure in der Ferkelaufzucht. J. Anim. Physiol. Anim. Nutr. 74, 235-242

Kirchgessner M., Roth-Maier D.A., 1975. Zum Einsatz von Zitronensäure in der Ferkelaufzucht. Züchtungskunde 47, 329-334

Lück E., 1986. Chemische Lebensmittelkonservierung. Stoffe, Wirkungen, Methoden. SpringerVerlag, Heidelberg

Paulicks B.R., Roth F.X., Kirchgessner M., 1996. Dose effects of potassium diformate (Formi ${ }^{\mathrm{TM}}$ LHS) on the performance of growing piglets. Agribiol. Res. 49, 318-326

Rehm H.J., 1961. Grenzkonzentrationen der zugelassenen Konservierungsmittel gegen Mikroorganismen. Z. Lebensm. Unters. Forsch. 115, 293-303

Risley C.R., Kornegay E.T., Lindemann M.D., Wood C.M., Eigel W.N., 1992. Effect of feeding organic acids on selected intestinal content measurements at varying times postweaning in pigs.

J. Anim. Sci. 70, 196-206

Roth F.X., Eckel B., Kirchgessner M., Eidelsburger U., 1992. Zum Einfluß3 von Ameisensäure auf $\mathrm{pH}$-Wert, Trockenmassegehalt, Konzentration an flüchtigen Fettsäuren und Milchsäure im Gastrointestinaltrakt. J. Anim. Physiol. Anim. Nutr. 67, 148-156

Roth F.X., Kirchgessner M., 1988. Zum Einsatz von Essigsäure in der Ferkelfütterung. Landwirtsch. Forsch. 41, 253-258

Roth F.X., Kirchgessner M., 1989. Bedeutung von pH-Wert und Pufferkapazität des Futters für die Ferkelfütterung. 2. Mitteilung. Effekt einer pH-Absenkung im Futter durch ortho-PhoshorsäureZusatz auf Wachstum und Futterverwertung. Landwirtsch. Forsch. 42, 168-174

Roth F.X., Kirchgessner M., Paulicks B.R., 1996. Nutritive use of feed additives based on diformates in the rearing and fattening pigs and their effects on performance. Agribiol. Res. 49, 307-317

Roth F.X., Kirchgessner M., 1997. Formic acid as a feed additive for piglets: Nutritional and gastrointestinal effects. Proceedings of the $7^{\text {th }}$ International Symposium on Digestive Physiology in Pigs. St. Malo, France, pp. 498-501

Roth F.X., Kirchgessner M., Eidelsburger U., 1993. Zur nutritiven Wirksamkeit von Milchsäure in der Ferkelaufzucht. Agribiol, Res. 46, 229-239

Sutton A.L., Matthew A.G., Scheidt A.B., Patterson J.A., Kelly D.T., 1991. Effects of carbohydrate sources and organic acids on intestinal microflora and performance of the weanling pig. Proceedings of the $5^{\text {th }}$ International Symposium on Digestive Physiology in Pigs. Wageningen, The Netherlands, pp. 442-447

Taylor W.H., 1959. Studies on gastric proteolysis. Biochem. J. 71, 73-85 